\title{
Rethinking overlap and duplication: Federalism and Environmental Assessment in
}

\section{Australia}

Politicians, policy makers and academics have long been troubled by the overlap and duplication, which characterises many federal systems. Overlap and duplication is, according to the Australian Prime Minister, Kevin Rudd, “... one of the core problems at the moment [with] the way the federation works. It's duplication, overlap, cost shift, blame shift” (Rudd 2008b). ${ }^{1}$ The problem of overlap - in health, in education, in business regulation, and in energy and transport - is a theme he returned to regularly in his first few months in office (Rudd 2008a,c,d,e; also Rudd 2007). And he is not the only one. In Australia, both Prime Ministers and Premiers have railed against overlap and duplication as the cause of low productivity, poor service delivery and business frustration (See for example, Howard 2005a,b,c; Brumby 2008; Bligh 2008). Nor is it a new concern. Nearly 80 years ago, Warner (1930. 120) observed "the existence of two independent systems of governmental activity causes expensive duplication and endless conflicts” (see also Whitlam 1983). More recently the elimination of overlap and duplication was one of the prime motivating forces behind Australia’s New Federalism agenda of the early 1990s (see for example Painter 1998a; Fletcher and Walsh 1992). Overlap has also generated concern amongst politicians, practitioners and scholars in other federations including Canada (Salvail 1992; Dion 1996), the United States (see for example Field 1992, 446-7; Lee 1994, 83) and, to a lesser extent, Switzerland (Armingeon 2000, 112, 125). ${ }^{2}$

Is this condemnation of overlap warranted? Is it always to be one of the drawbacks of federalism, or are there circumstances in which it is a strength? In Canada, Brown (1994), and Armit and Bourgault (1995) suggest the problem has been exaggerated, the costs overstated, and the advantages undervalued. In Australia, Walsh (2008, 556-8) and Pincus (2008), point to the potential economic benefit. US scholars also emphasis the strengths of a multi-level system which involves different levels of government. For example, Esty (1996) 
rejects what he sees as a rush to decentralize environmental regulation, arguing instead for multi-level engagement. Indeed, Engel (2006) argues environmental law in the US has benefited from the absence of a static allocation of authority. A clear division of roles and responsibilities, she contends, would be unable to militate against agency capture; encourage legal jurisdictional disputes; and reduce opportunities for policy innovation and experimentation. Rabe (2007b) too sees the promise in multi-level engagement in environmental policy making, pointing to a range of State initiatives and examples of interstate collaboration (see also Rabe 2007a and 2008). More generally, Landau (1969) suggests that overlap, or more precisely, redundancy, is one of strengths of federalism.

In the 1990s, the regime for regulating environmentally sensitive developments in Australia underwent a major overhaul. Motivated by a quest for economic efficiency and political certainty, the new regime largely succeeded in reducing overlap and duplication. Built on the principle of subsidiarity, the new system was hierarchical with each level of government taking responsibility for developments in its own sphere of responsibility within a common conceptual framework, ecologically sustainable development (ESD). This new regime provides us with an ideal opportunity to question the political consensus on the benefits of eliminating overlap. Whilst it may have delivered administrative and business efficiencies, the new policy framework has struggled to effectively address the demands of this complex policy domain which is characterized by its interrelatedness. The paper argues that duplication, overlap and redundancy perform a useful function in a complex policy domain such as the environment where the science is uncertain and the politics fraught. Indeed, what appears as a straightforward administrative reform has effectively reduced the checks and balances that are the hallmark of a federal system of government.

The paper begins looking at redundancy, duplication and overlap: what is it?; why does it develop?; and what are its costs and benefits? The following section provides a brief overview of the Australian federal system. The paper then turns to examine the Australian environmental assessment and approval regime beginning with the expansion of central 
government responsibility for the environment. The paper goes on to detail the conceptual framework and legislative regime developed in the 1990s to reduce overlap and duplication within the consistent set of priorities and guidelines provided by ESD. The paper then discusses the implications of this change not only for the natural environment but also for the political system as a whole.

\section{OVERLAP, DUPLICATION AND REDUNDANCY}

The terms overlap and duplication lend themselves to political sloganeering but what do they actually mean? Brown (1994) defines "overlap” as a situation where we have more than one government operating in the same policy domain. More precisely, it occurs when multiple levels of government provide similar goods and services to similar clients. Duplication is a subset of overlap and describes a situation where more than one level of government provides the same goods and services to the same clients. Redundancy, a consequence of duplication, occurs when involvement of the additional level of government is of no benefit and may even detract from the overall benefit. Overlap, duplication and redundancy are a product of the concurrency which characterises federal systems.

This concurrency has not always been appreciated. Wheare's (1963) influential work emphasised the co-ordinate nature of federalism but where Wheare focused on legal arrangements, Davis (1956) drew attention to fiscal and political aspects, both of which suggest concurrency. Concurrency also appeared in the work of other noted federal theorists such as Birch (1966) who argued that federations were distinguished by both their interconnectness and their scope for autonomy and Sawer (1969), for whom, co-ordinacy and concurrency represented stages in the evolution of federations. Grodzins' (1984) characterisation of the US federation as a marble cake proved to be an enduring culinary metaphor for the policy landscape, a theme taken up by Elazar (1966) and a generation of scholars of intergovernmental relationships. ${ }^{3}$ 
Irrespective of the intentions of the constitutional architects, the neat division of powers, encapsulated in the terms dual or co-ordinate federalism, has not eventuated partly because the realities of politics do not lend themselves to a tidy separation (Thorlakson 2003). Even in situations where we find a relatively strong early commitment to the idea of dual federalism, as in the United States, State and Federal governments have long overlapped (Agranoff and McGuire 2004, 498-500). The Canadian and Australian experiences clearly demonstrate that an express allocation of powers to the provinces (as in Canada), or to the central government (as in Australia), has done little to eliminate the problem. Indeed, Galligan (1995) sees concurrency as an integral part of Australia’s federal arrangements.

Overlap, duplication and redundancy, it seems are pervasive but are they necessarily problematic? Landau (1969) argues that redundancy may be of considerable utility because it provides a kind of insurance. Redundancy is a fail-safe, the kind of check and balance that federalism is well suited to provide. Redundancy, according to Landau (1969, 352), is the organizational expression of the principle of check and balance, of action and reaction, that the founders of the US constitution were so anxious to attain. Although commonly associated with waste, redundancy is not only unavoidable but desirable. It means that if one part fails, another can step in, providing reliability and certainty in a world that is inherently unstable and unpredictable. Rather than promoting inefficiency, "redundancy serves many vital functions ... it provides safety factors, permits flexible responses to anomalous situations and provides a creative potential” (Landau 1969, 356). O’Toole $(1990,400)$ acknowledges the strengths of redundancy theory, but suggests it may be more applicable when there is general agreement. He warns it may be less benign in circumstances where the various elements have their own independent sources of legitimacy and represent different constituencies with different interests. In such circumstances, he warns, redundancy can lead to "endless cycles of bargaining”. It is such circumstances, however, where overlap may be most valuable.

Elazar (1985, 32) argues, federal systems, with their "multi-centric form and non-centralized organization of power”, may be more democratic than other forms of political organisation. 
This is, in part, because of overlap and the way in which it can limit the power of government. Overlap offers more opportunities for a broader variety of interest groups to influence the policy process. Baumgartner and Jones (1991), concerned to explain dramatic policy change, found the multiplicity of fora for lobbying was an important factor in undermining the powerful alliances between industry, bureaucracy and politicians in the policy community which had grown around the nuclear industry in the US. Opponents of the status quo were able to approach other fora - agencies and committees that were open to alternative ways of constructing the policy area - to promote their cause. It was this which eventually undermined the policy subsystem and allowed for dramatic change. According to this argument, federalism, with its overlaps, can provide a powerful pluralistic antidote to the undemocratic alliances between government and vested economic interests. Baumgartner and Jones (1991, 1046) argue their work shows, "the importance of multiple and competing venues of policymaking within the federal system and demonstrates the opportunities for overturning what appear to be powerful systems of limited participation” (italics added). The relevance extends beyond the US. Richardson (2000) suggests the "Europeanization" of many policy areas through the European Union has opened up more opportunities for interest groups to influence the policy process. Efforts to eliminate overlap, by reducing the range of venues, make it more difficult for alternative voices to gain a hearing and influence the policy agenda. A policy regime which divides responsibility effectively hands sole authority to one level of government, and often to one agency. This significantly reduces the opportunity for opposing interests to lobby. Baumgartner and Jones (1991) argue that different agencies adhere to quite different understandings of a policy problem, and to gain traction, lobby groups must approach agencies which share their understanding. A single agency equates to a single understanding and thus closes off the possibility of shifts in policy direction.

This literature suggests that overlap, duplication and redundancy can serve a useful purpose. Before we can explore the implications of such an analysis, however, we need to briefly 
outline the main contours of the Australian federal system and efforts to minimise or eliminate the phenomena.

\section{AUSTRALIAN FEDERALISM, CONCURRENCY, OVERLAP, DUPLICATION AND REDUNDANCY}

Australia is one of the oldest federations. Founded in 1901, it was a product of the "coming together” of six autonomous British colonies. ${ }^{4}$ Reluctant to relinquish, their existing institutions, the founders envisaged a minimalist role for the new Commonwealth government and gave it few exclusive powers. Instead the new constitution enumerated a range of powers which the new central government would share with the States. Most of these concerned relations with the wider world; the creation of a national economy; and limited social issues. To deal with this inbuilt concurrency, the constitution specified that the Commonwealth would prevail in cases of inconsistency. Remaining responsibilities resided with the States, effectively leaving the States in charge of many significant functions including health, education and law and order (Fenna 2004 168-71). Importantly, for our discussion, the States also retained responsibility for land use planning, natural resource management and other areas of environmental impact. ${ }^{5}$

In the century since federation, however, the centre has continuously encroached on areas of State responsibility albeit in an incremental and somewhat contradictory way (Galligan 2008). Whilst formal constitutional change has largely remained a dead letter, the Australian High Court, fiscal arrangements, and politics have all facilitated an increasing centralisation. For example, in the 1942 Uniform Tax Case, the Court effectively handed the Commonwealth sole control of income tax thereby exacerbating a vertical fiscal imbalance and providing the Commonwealth with significant financial leverage in its relations with the States. This leverage was all the more powerful because the Commonwealth had the capacity to dictate the terms and conditions of grants it made to the States (Fenna 2008). ${ }^{6}$ In the 1980s, in the Koowata and Tasmanian Dams Cases, the Court recognised the Commonwealth's authority under its external affairs power to intervene in areas of State responsibility to meet international obligations (Boer 1992, 261-3). ${ }^{7}$ More recently, in the 2006 Work Choices Case, the High Court determined that the Corporations' power gave the Commonwealth authority to make laws relating to any aspect of a corporation's activities (Stewart and Williams 2007). ${ }^{8}$ 
Whilst the Australian federation has been subject to strong centripetal forces in Australian federalism, the States, nevertheless, have continued to play a significant role in both policy making and implementation (Parkin 2003, 106-8), and the concurrency embedded in the Australian federation means that the system has continued to exhibit characteristics of Grodzin's "marble cake" of shared activities. ${ }^{9}$ It is this concurrency which has generated much of the anxiety about the state of the Australian federation because concurrency, with its inevitable overlap, sits uneasily with the principles of economy and efficiency which characterise much of contemporary public administration thinking. As O’Toole (1990, 397) observes,

... the dominant theoretical and practical impulses in the field of public administration with have long been toward organizational integration; the benefits of non-duplicative structures; the values of efficiency; [and] the advantages of smooth, nearly frictionless action.

These concerns, for integration, efficiency and the absence of duplication, permeated Australian thinking about federalism over the past two decades and informed the New Federalism agenda of the 1990s. ${ }^{10}$ The agenda originated with a quest for improved economic efficiency and international competitiveness, and centered on clarification of roles and responsibilities and the elimination of overlap and duplication. ${ }^{11}$ In 1990, following the lead of several State premiers from both sides of politics, ${ }^{12}$ Labor Prime Minister Bob Hawke launched his plan for a “Closer Partnership with the States”, which involved taking “sensible, practicable steps to get better cooperation within the framework of the Federal Constitution” and also to "apply the spirit of national cooperation in a new approach to reform of the Constitution itself” (cited in Galligan \& Walsh 1990, 2; see also Galligan 1993, 292). This was, in many ways, an important initiative, not least because it foreshadowed both institutional and policy reform.

Australia's collaborative architecture was ill developed. The Constitution provided for the establishment of two co-operative federal institutions - the Senate and the now defunct Interstate Commission although neither operated effectively as such. ${ }^{13}$ This meant there were few opportunities for engagement between Commonwealth and State leaders beyond the 
annual Premiers' Conferences which were typically marked by acrimony and political grandstanding. ${ }^{14}$ New Federalism prompted the emergence of a new institutional forum, Council of Australian Governments (COAG) in 1992 following a series of Special Premiers Conferences. Since its creation, COAG has a chequered existence partly because its lack of constitutional status means that its fortunes depend on the Prime Minister's level of commitment. $^{15}$

This quest for a new cooperative rationality was embodied in the principles which underpinned the new institutional arrangement. At the Special Premiers Conferences in 1990 and 1991, the leaders agreed to four principles, those of nationhood, subsidiarity, structural efficiency and accountability (FSRC 1998). All, in their own way, represented a commitment to eliminating overlap, duplication and redundancy. This commitment can also be seen in the program of policy reform the leaders set themselves which included such elements as the establishment of a national electricity grid; a uniform road transport regime for heavy vehicles; a National Rail Corporation; national food standards; and uniform building regulations (Painter, 1998b, 37-40; Keating and Wanna 2000, 152; Carroll and Painter 1995, 9).

The new federalism of the early 1990s, was not a call for a "dual federalism”, where different jurisdictions went their own way. Instead, it emphasized collaboration (Painter 1998). It was concerned with the collective pursuit of national priorities, often using the same strategies. This was evident in the implementation of National Competition Policy, for example, where all jurisdictions agreed to apply the same methodologies in pursuit of economic reform (Hollander 2006b). Thus the commitment to clarifying roles and responsibilities (and its concomitant reduction in overlap and duplication), was contained within an acceptance of common goals and a common conceptual framework. The vision of more streamlined regimes where Commonwealth and State frameworks slotted together to create a compatible whole continues to inform thinking about the Australian federation. In a 2007 paper, 
Twomey (2007) argues for a clarification and reallocation of roles and responsibilities to reduce duplication and overlap (see also Twomey and Withers 2007).

\section{THE AUSTRALIAN ENVIRONMENTAL ASSESSMENT AND APPROVAL REGIME}

As we have seen, Australia's founding fathers were parsimonious in the allocation of powers to the new Commonwealth, and the newly created States retained many of the responsibilities they had enjoyed as colonies including control of resource management and land use planning. And that is the way it remained for the first seventy years or so. The States, motivated by a developmental ethos and the revenue potential of resource exploitation, paid little heed to environmental considerations (Walker 1999, 31; Walker and Cowley 1999, 7). The situation began to change in the 1970s. Whilst some State governments began to take environmental issues seriously, performance was patchy (Davis 1985, 3). Environmentalists, frustrated by the intransigence of State governments, started to look to the Commonwealth to protect the environment from unsympathetic development proposals. This intransigence was most marked in Queensland, where Kellow and Niemeyer (1999) attribute it to a decentralised population and comparatively low levels of industrialisation, and in Tasmania, where Kellow (1989) points to the strength of the Hydro Electricity Commission and its philosophy of hydro-industrialisation. By the early 1970s, the Commonwealth had started to test the constitutional boundaries by asserting its authority over the marine environment, culminating in the establishment of the Great Barrier Reef Marine Park (Bowen and Bowen 2002, 32855). Other constitutional heads of power were also useful. ${ }^{16}$ In 1977, the Commonwealth halted sandmining on Fraser Island, ${ }^{17}$ now a World Heritage site, by suspending the miner's export licence (Christoff 1994), and in 1983, it used its external affairs powers to block the damming of the Franklin River (Curran 1998). ${ }^{18}$ With the Commonwealth's authority confirmed by the High Court in the Franklin Dam case which followed its intervention, it 
found itself under increasing pressure to intervene to protect environmentally sensitive areas across the country. Whilst there was political capital to be made, there were also significant costs (Economou 2004) and the Commonwealth was caught in a three-way battle between environmentalists, developers and State governments. As Kellow $(1995,205)$ points out, the Commonwealth's problem was never one of power but rather one of politics and as the decade wore on, it needed a way of managing what was becoming an increasingly untenable political, and policy, position.

In the early 1990s, the Commonwealth had both the political impetus and the policy capacity to drive change. The microeconomic reform agenda with its quest for economic efficiency had provided the architecture for a new co-operative relationship with the States, and interest group and electoral pressures provided the political momentum for change. The scene was set for a renegotiation of arrangements for managing the environment in a way which clarified roles and responsibilities and reduced overlap and duplication. At the October 1991 Special Premiers' Conference, the heads of government agreed to work towards an arrangement which would better define the roles of the different levels of government with an eye to reducing disputes between governments and providing business with greater certainty as well as ensuring better environmental protection (Australia 1992a). Such a development was necessary because, according to the communiqué:

overlapping responsibilities can lead to duplication or inconsistent approaches, with resulting uncertainties, inefficiencies and higher costs to industry and the community as well as inadequate protection for the environment (cited in Clearly 1990, 6).

Whilst it was difficult to bring all of the States on board - eleven drafts were reportedly rejected (Chamberlain 1992, 16) - the ensuing "Intergovernmental Agreement on the Environment”, signed in May 1992, provided the framework for the subsequent reconfiguration of arrangements. Echoing the earlier communiqué, the Agreement highlighted the need for a clear and unambiguous delineation of roles and responsibilities between levels of government and the streamlining of administrative processes as essential to 
improve efficiency and effectiveness, as well as enhancing democratic accountability (Australia 1992a).

Later in the year, at the very first COAG meeting, the governments also agreed to a common conceptual framework, that of ESD. Henceforth, they declared, "the future development of all relevant policies and programs, particularly those which are national in character, should take place within the framework of the ESD strategy” (COAG 1992). Australia's 1992 “National Strategy for Ecologically Sustainable Development” defined ESD as:

... using, conserving and enhancing the community's resources so that ecological processes, on which life depends, are maintained, and the total quality of life, now and in the future, can be increased (Australia 1992b). ${ }^{19}$

The preservation of biodiversity and the protection of intergenerational equity were central to ESD. ESD was built on the presumption that present generations were obliged to ensure the welfare of future generations and to do this they needed to maintain essential ecological processes, especially those that supported life. Hence, decision making needed to incorporate environmental and social, as well as economic, considerations. It was important, therefore, to find ways to value environmental assets and outcomes. The natural environment could no longer be used as a free good, a resource to be pillaged and a sink for unwanted by-products. Instead, environmental resources had to be managed in a sustainable way so that they could continue to be used into the future. To ensure this occurred, ESD required the precautionary principle be observed. Hence, in cases "where there are threats of serious or irreversible environmental damage, lack of full scientific certainty should not be used as a reason for postponing measures to prevent environmental degradation” (Australia 1992b).

The "Intergovernmental Agreement" and the "National Strategy" were critical to the new environmental framework for assessing and approving development projects. The “Agreement”, with its emphasis on clarifying roles and responsibilities, offered the Commonwealth a way of alleviating the mounting political pressures and assuaging State concerns that their authority was being whittled away. It also met the expectations of the 
microeconomic reform agenda with its emphasis on increasing economic efficiency through improved government processes in particular the elimination of overlap and duplication. However, these twin aspirations could only be achieved if all jurisdictions accepted a common conceptual framework. This was important for two reasons. First, it reassured environmentalists that the Commonwealth was not simply abandoning the environment, and second, it provided business with a measure of consistency in environmental decisionmaking. The "National Strategy", with its emphasis on ESD, offered this consistency by providing a conceptual framework to guide decision making across the country in all jurisdictions. With the building blocks in place, we need to see how the Australian environmental assessment and approval regime, which developed after 1992, operated to reduce overlap and duplication within the common conceptual framework of ESD.

\section{A Shared Conceptual Framework}

A common conceptual framework was an important component of the new regime. It was to be the unifying element, bringing key environmental priorities to the fore and providing consistency across all levels of government. A survey of key pieces of Commonwealth, State and Territory legislation shows that, generally, the principles of ESD, articulated in the "National Strategy", did find their way into State and Commonwealth legislation. They framed environmental policy-making in most jurisdictions and informed planning processes. The principles of ESD were explicitly stated in the objectives of the Commonwealth's key piece of environmental legislation, the Environmental Protection and Biodiversity Conservation (EPBC) Act. This feature was, according the then Minister, Senator Robert Hill, one of the innovative features of the legislation and demonstrated the Commonwealth's deeply held commitment to the environment (Cwlth 1998, 4797).

The Commonwealth was not alone in giving ESD legislative force. The principles were spelled out in legislation setting up the Queensland Environment Protection Agency, the 
Western Australian and NSW Environmental Authority, and Victoria's Sustainability Commission. ${ }^{20}$ They also informed the States' planning processes, either explicitly articulated in the objectives of the relevant legislation or indirectly by reference to the States' environment authority. In Tasmania, for example, the Resource Management and Planning System outlined the principles of ESD which were also spelled out in the Resource Planning and Development Act (Tasmania 2003, 6-7). Other pieces of legislation, such as the Land Use Planning and Approvals Act 1993 (Schedule 1) and the State Policies and Projects Act 1993 (Schedule 1) referred back to the Planning System or drew on key ESD principles. Similarly, South Australia's Development Act 1993, aimed to ‘promote ... the principles of Ecologically Sustainable Development' and made express mention of the precautionary principle and intergenerational equity (s10). Whilst less well developed, the notion of ecological sustainability was also evident in Queensland's Integrated Planning Act 1998, Victoria’s Planning and Environment Act 1987 and NSW's Environmental Planning and Assessment Act 1979 .

It is important not to overstate the impact of ESD, however, and the extent to which these principles informed decision making is debatable. There were some important exclusions. For example, ESD was not mentioned in Tasmania's Forestry Act 1920, and the Forest Practices Act $1985^{21}$ nor in Queensland's State Development Act. We also need to consider how the principles shaped practice. A 2000 Productivity Commission report into the implementation of ESD by Commonwealth Departments found they struggled to realise their ESD goals because of poor policy process (Productivity Commission 1999). England (1999, 125 ) is also cautious about exaggerating the impact of including sustainability principles in the Queensland Integrated Planning Act, because the Act does not specify how these are to be put into practice. Dovers (2001; 2002) argues that, despite formal commitment to ESD, sustainability remains institutionally weak and politically compromised in the face of stronger economic rationalities (see also Auditor General 2003; Mercer and Marden 2006, 197-8.). Nevertheless, Thom (2004) sees promise in the formal incorporation of the principles of ESD 
into policy. Although Australia does not have the same tradition of litigation as the US (Kelemen, 2004), the articulation of ESD principles in legislation provided a legal avenue for critics of development projects. In the Tuna Boat case, for example, opponents of a fish farm development in South Australia argued that those approving the project had failed to consider the precautionary principle (Fisher, D.L. 2001; Fisher, E. 2001). Such an objection was only possible because the principles formed part of the legislation.

Despite the reservations, the fact that the principles were included in Commonwealth and State legislation was an key element in the push to reduce overlap and duplication because it lent a measure of coherence to the regime. It ensured that the assessment and approval process at all levels, not only incorporated environmental factors into their decisions, but also considered them in a way which was consistent. This was important if efforts of the State and Commonwealth regimes were to dovetail into a harmonious whole.

\section{An Integrated Legislative Regime}

The key to reducing duplication and overlap lay in clarifying roles and responsibilities, albeit within a consistent framework. As we have seen, during the 1970s and 1980s, the Commonwealth's role in environmental assessment and approval expanded, frequently overlapping with traditional areas of State responsibility. This section looks at the way in which Australian governments worked to simplify and co-ordinate their legislative regimes and reduce overlap and duplication beginning with the Commonwealth.

\section{The Commonwealth EPBC Act}

In 1997, following an inquiry into the Commonwealth's environmental powers, COAG confirmed the earlier "Intergovernmental Agreement”, agreeing, in principle, to rationalise Commonwealth and State responsibilities in relation to the environment (Kennedy et al. 2001, 299; COAG 1997) This intention was put into effect through the 1999 EPBC Act. The Act aimed to clarify the Commonwealth's role within a framework which recognised the States' 
primary role in the delivery of good environmental outcomes, promising a "seamless integration” of systems for environmental assessment and approval (Cwlth 1998, 4795-98). How was this achieved?

The EPBC Act clearly and explicitly delineated the Commonwealth's responsibilities by specifying so-called "matters of national environmental significance” (MNES). These MNES were critical because they clearly delineated the scope of the Commonwealth's engagement in environmental matters. Henceforth, the Commonwealth could and would only involve itself where developments threatened to impact on MNES. Specifically, MNES covered World Heritage properties; Ramsar wetlands; nationally threatened species and communities; migratory species protected under international agreements, nuclear actions; and the Commonwealth marine environment (EPBC Act 1999 s12). The Parliament added National Heritage in 2003 (Peel and Godden 2005, 678). Under the Act, the Commonwealth only needed to consider proposed actions which had the potential to impact significantly on any of the MNES, and then only in terms of that aspect of the proposal. Other impacts, significant or otherwise, were left for the States to deal with.

The EPBC Act also sought to eliminate duplication by providing for bilateral agreements with the States and Territories. These agreements allowed the Commonwealth to delegate authority to undertake assessment and approval in relation to MNES to the States. Whilst Approval has never been delegated, the Commonwealth concluded bilateral agreements with most of the States and Territories beginning with Tasmania in 2000. By July 2008, there were six bilateral agreements between the Commonwealth and the States with an additional under consideration (Australia 2008a). In addition, the EPBC Act allowed for accreditation of State processes on a case by case basis. Accreditation was initially more important but, as time went by, bilateral agreements accounted for more assessments (Australia 2008b). Like many of the State regimes, the Commonwealth also used a variety of assessment approaches ranging from a full public inquiry to "preliminary documentation”. The later relied solely on material provided by the proponent and has been the most common form of assessment to 
date. In many cases the preliminary documentation supplied consisted of material prepared to meet the requirements of the State regimes. In this way, the EPBC Act further minimised duplication (Australia 2008b).

In summary, the $E P B C$ Act reduced overlap and duplication in several ways. First it clearly articulated the scope of Commonwealth responsibility and promised that the Commonwealth would restrict its engagement to these issues, the MNES, alone. Second, it recognised and accepted State and Territory assessments either on a systemic or case-by-case basis. This meant that proponents had only to go through one assessment process. Third, it accepted paperwork which had been prepared for State assessment for its own processes.

\section{State and Territory Regimes}

Reductions in overlap and duplication required more than action at the Commonwealth level. State and Territory governments also needed to reform their legislative regimes to provide for expeditious processing of development applications. As the discussion below shows, there was little in the way of horizontal harmonisation with each jurisdiction adopting its own distinctive regime for assessing and approving development proposals. Whilst some operated a single integrated system, most embraced a two tier regime with local government assuming responsibility for proposals with limited impact and State governments taking control of the process for more significant projects. Despite their differences, they were all animated by a common goal - that of reducing overlap and duplication. The regimes developed from the 1980s onwards consolidated numbers of Acts often with the express aim of eliminating multiple applications and requests for documentation. Along with a streamlined process, and shared documentation, most State level regimes clearly articulated the roles and responsibilities of local and State governments albeit with a good deal of Ministerial discretion.

Although Australia does not have a strong tradition of subsidiarity in land use planning (Gleeson 2002, 143), the principle that decisions are best managed at the lowest appropriate 
level of government (albeit with strong State level oversight) has informed the regimes enacted in most States where local government has typically dealt with proposals of local significance. $^{22}$ The various State planning regimes assigned local government responsibility for assessing and approving most planning and development decisions which fell solely within their jurisdiction. ${ }^{23}$ Their scope for discretion was circumscribed however, by State government approved planning schemes, which largely set the parameters for land use, and by overarching State level environmental policies and codes.

Activities which had the potential to impact more significantly on the environment had to be referred to the State' specialist environmental agency in many jurisdictions. In Tasmania, for example, local governments could only approve activities with low level environmental impact. They had to refer potentially more harmful activities to that State's Environmental Protection Agency for assessment (Environmental Management and Pollution Control Act 1994). In South Australia, local authorities also had to refer environmentally significant activities, defined by industry type, to their Environmental Protection Agency for assessment and, in some cases, approval (Development Regulations Sch8). Similarly, in Western Australia, the Environmental Protection Agency was responsible for assessing activities which are likely to have "significant environmental impacts". Victoria’s referral criteria were expansive, and unusually, included greenhouse gas impacts (Victoria 2006, 6-7). In Queensland and New South Wales, by contrast, local authorities retained more of the responsibility for assessment and approval although their planning schemes had to conform with a number environmental codes and laws dealing with dealing with vegetation management, coastal management, wild rivers, and so on (Integrated Planning Regulation 1998). In Queensland, the Minister for Infrastructure and Planning, however, could override local authorities if there was a risk of significant environmental harm (Integrated Planning Act 1993 s2, 5).

With local government assuming responsibility for projects of local significance, State governments retained authority over projects of State level significance. In Queensland, the 
State government could take over responsibility for larger projects through its State Development and Public Works Organisation Act 1971. In several other States, provision for Ministerial intervention was contained within the primary planning act. In NSW, for example, the 1985 Environmental Planning \& Assessment Act provided the legislative foundation for local government action but the State retained the capacity to intervene in relation to major projects under Part 3A State Environmental Planning Policy (Major Projects) 2005. Similarly South Australia’s 1993 Development Act set up the regime for local planning and assessment with provision for ministerial intervention to cover major developments (S46). The definitions of projects of State significance varied across jurisdictions. In NSW for example, the Policy specified “development types” (industries) with threshold values, and specific sites or locales (State Significant Sites), although the Minister had the discretion to include projects which did not fit into these categories (NSW 2007). In South Australia, major developments were defined simply by reference to their economic, social or environmental impacts (Development Act s46). In Queensland, the guidelines were not as clear but in declaring a project of "State significance" the State's coordinator general had to take account of existing planning schemes, economic or environmental impacts, or infrastructure requirements (SDPWO Act s26).

Significance invariably changed the requirements in relation to environmental assessment. Most States relied on a range of assessment tools depending on the nature of the project and the significance of potential environmental impacts. The Western Australian regime, for example, provided for six different assessment methodologies ranging from a simple assessment based on the information supplied by the project proponent to a full public inquiry, depending on the potential impact of the project (Environmental Protection Act 1986). By contrast, the Queensland regime used the a singe tool - the Environmental Impact Statement - across the board (IPA s5).

This brief overview of the State regimes reveals that in their own way, each sought to distribute roles and responsibilities to reduce duplication and overlap. Proposals were defined 
in terms of their significance and likely environmental impact and processed accordingly. Small scale proposals, with minimal impact were handled by local authorities at a local level, more substantial proposals with the potential for significant impact were handled by State governments at a state level. And whilst the documentation requirements often varied according to the regime and the level of impact, multiple submissions were usually no longer needed.

Taken together the Commonwealth and State regimes represent a reasonably unified system of environmental assessment and approval with only limited overlap. Whereas the Commonwealth had once exercised wide ranging powers, under the new regime its role was restricted to the MNES. Furthermore it could, and did, recognise the States' assessment regimes, allowing them to be used to evaluate impacts in its sphere of responsibility. At State level, environmental impacts were assessed and approved by local governments, environmental authorities or State government ministers. Proponents may still have had to deal with two levels of government but the overlap in terms of areas of concern was limited and they could often use the same documentation to meet State and Commonwealth requirements.

\section{THE IMPLICATIONS OF REDUCING OVERLAP AND DUPLICATION}

Australia's current environmental assessment and approval regime has gone a long way towards minimising the overlap and duplication that characterises policy implementation in a federal system. Although the various State and Territory regimes are different from each other - a potential source of frustration for entities operating across State lines - they do dovetail with those of the Commonwealth. The aim of clarifying roles and responsibilities has been realised with the designation of MNES, and the Commonwealth has recognised and accepted some State assessment procedures thus ending the need for multiple assessments. But has this ensured better environmental outcomes? This section focuses on two aspects of the regime which suggest the contrary. The first focuses on the nature of the policy domain 
and its inherent complexity. It asks if the environment as a policy area lends itself to the clear delineation of roles and responsibility and the concomitant reduction in overlap. The second explores the more general lessons for federalism and asks if governments, in their quest for a more stream-lined regime, have abandoned the checks and balances that constitute one of federalism's strengths.

\section{MNES and the Interconnectedness of the Environment}

Environmentally issues are invariably complex. They are characterised by interconnectedness and this in turn makes them difficult to confine to territorial and other jurisdictional boundaries. Ecosystems, and their constituent parts, - air, water, species and habitant cannot simply be contained within borders constructed by politics and culture. The concept of ESD recognises this. It is a holistic approach that not only emphasises the interconnections between economic, social and environmental factors and the need to consider all three in decision making, but also acknowledges the interrelatedness of ecological processes. It is implicit in notions such as ecological integrity and biodiversity conservation, both contained within the concept of ESD. Ecological integrity refers to the "self creative capacities of life to organise, regenerate, reproduce, recreate, adapt, develop and evolve itself” (Miller \& Rees 1991, 11). Biodiversity is concerned with the diversity of genes, species and ecosystem and these cannot be conceived of in isolation and are best understood and protected in situ (CBD 2000, 2).

Whilst ESD emphasises co-dependence and inter-relatedness, the Australian regime in which it is embedded divides up, not only roles and responsibilities, but also the environment itself. The very concept of MNES, the idea that some matters can be separated from their context and handled by a different level of government, effectively downplays this interconnectedness. Part of the problem is the present state of knowledge. As Macintosh (2004, 304) points out, our understanding of species, communities and habitats especially in relation to invertebrates and some plants is far from complete and while it can be dealt with in 
part through the application of the precautionary principle, even this presupposes a higher level of understanding and identification than currently exists (see also Macintosh and Wilkinson, 2005).

The courts have acknowledged, to an extent, the artificiality of the divisions. In the 2001 Flying Fox case, the Federal Court was presented with evidence that an electric grid designed to protect a lychee crop from flying foxes was likely to impact adversely on the Wet Tropics World Heritage area ${ }^{24}$ despite the fact that the grid was located outside the boundaries of the protected area. Although other factors proved to be more important in the final determination, the court did consider the connection between a single species and its role in the "ecological and evolutionary processes of the Wet Tropics World Heritage Area”. Of particular importance was the flying foxes' role in the pollination and dispersal of seed (McGrath 2001, 24; see also McGrath 2004; 2008, 341-2). According to Kennedy et al (2001), the case clearly recognised that responsibility for World Heritage values extended beyond the boundaries of the park. This expansion was confirmed in the Nathan Dam case. In this case, the Court considered the long term impact of a large dam on another World Heritage area, the Great Barrier Reef. The Court was interested in the impact, not of the dam itself, but of the industry that would follow in its wake. The Court found that the Commonwealth minister was obliged to consider the impact of these downstream activities (primarily irrigated cotton growing and processing) on the health of the reef. Peel and Godden $(2005,684)$ argue this case was important because of its acknowledgement of indirect or cumulative effects of an action over time and space. Other legal challenges have not been as successful in widening the application of the EPBC, however. In two separate cases (Anvill Hill, and Isaac Plains and Sonoma Coal), environmentalists argued proposed coal mines required Commonwealth approval because they would contribute to global warming which in turn will threaten the Great Barrier Reef and impact on endangered species, both MNES (Clayton Utz 2005; Thomas and Daniel 2007). In both cases, environmentalists were forced to follow this rather tendentious argument because the regime failed to include greenhouse gas as a MNES and 
this points to the broader problem of the restricted list. These cases show that the Courts can only go so far and legislative change is required if the list of MNES is to be expanded and the problem of interconnectedness addressed.

Such legislative change has not been forthcoming. Since its promulgation in 1999, there has been little attempt to expand the list of MNES with only one matter has been added. This is despite the fact that the 1997 COAG agreement identified some thirty MNES including greenhouse and ozone depleting gasses, and water and land degradation. In the past decade, these problems have become more rather than less pressing but the Commonwealth has thus far declined to extend the list. This has arguably created new problems especially in areas such as catchment management. It has also proved difficult to have new species or habitats added to the endangered list, another aspect critical to the preservation of biodiversity. The original 2000 list nominated 1568 species and twenty-three communities. Reviewing the list in 2004, Macintosh (2004, 304) was especially critical of the small number of ecological communities given that a national audit had identified 2981 threatened ecosystems. He acknowledged the species list was better but still inadequate. Moreover, it has only grown slowly. In 2007, 1697 species were listed and only thirty-eight communities (Australia 2007, 70). In their enthusiasm to eliminate overlap, governments have imposed divisions at odds with the nature of the policy domain.

Through the designation of MNES, the EPBC Act sought to restrict the Commonwealth's involvement in the assessment and approval process, thereby eliminating overlap with the States and Territories. This strategy is problematic for two reasons. First, it is inconsistent with ESD given its emphasis on interconnectedness and interrelatedness. Second, despite the rulings of the courts, the Commonwealth regime has demonstrated little capacity to respond to emerging issues because of the rigidities around the NMES.

\section{The Political Benefits of Overlap}

The elimination of overlap has other disadvantages. In their attempt to assert a dual model of 
federalism, in which each jurisdiction has exclusive responsibility for matters under its control, governments have lessened the opportunities for debate and intervention. It is not simply a problem arising from the transfer of responsibilities from one jurisdiction to the other but rather that some of the checks and balances which provided a measure of protection for the Australian environment in the past have been lost in the drive to eliminate overlap and duplication. Many of the environmental success stories of the past three decades have been achieved because of political antagonism between levels of government. Protection for important sites, such as Great Barrier Reef, the Franklin River and the Wet Tropics in far north Queensland was achieved only after political and legal wrangling between Commonwealth and State governments. For conservationists, federalism meant that battles lost in the State sphere could be referred to the Commonwealth for action and this was where they concentrated their efforts for much of the 1970s and 1980s (Hutton and Connors 1999; see also Bonyhady 1993). It was Commonwealth intervention, using a range of different powers, which ensured the preservation of what have become iconic Australian sites, such as the Tasmanian wilderness, the Wet Tropics, and Kakadu in the Northern Territory. Whilst, many of these, under the new regime, would be classed as MNES, others may not.

The importance of multiple arenas was clearly evident in Tasmania. In early 1970s, faced by the intransigence of a State government committed to economic development at any cost, the conservation movement appealed to Commonwealth to intervene ((Mulligan and Hill 2001, 224; Hutton and Connors, 1999, 118-22; Lines 2008, 59-61). The State’s Hydro Electricity Commission planned to inundate of Lake Pedder, a glacial lake surrounded by quartz sands in the state's rugged south west, as part of large hydroelectric scheme. The newly elected Labor government in Canberra proved to be more responsive; it established a Committee of Inquiry which recommended a moratorium (Higgs, 1978, 3) and offered to help fund an alternative scheme. The State government refused to co-operate, however, and Lake Pedder was lost. Nevertheless, the conservation movement learnt a valuable lesson (Sewell et al 1989, 153-4) and continued to use the multiple fora in its (successful) campaign to protect the Franklin 
River and in campaigns to conserve old growth forests from unsustainable logging activities. Indeed, in the latter, the Commonwealth Minister for the Environment, Senator Graeme Richardson, keen to capture the green vote, encouraged them to do so (Boer 1992, 269).

This is not to accept the arguments that the Commonwealth is inherently more sensitive to the environment (See for example Christoff 2002). . Although it has typically been more responsive to environmental demands, this has not always been the case. For example, between 1998 and 2000, the Commonwealth actively opposed State government plans to further restrict logging of old growth forests. Despite his best efforts, however, the then Commonwealth Minister for Forests, Wilson Tuckey, was unable to convince the Western Australian government from expanding protection for the Kari forests of the South West, or the Queensland government from phasing out all but plantation logging in South East Queensland (Hollander 2004). In this example, unusually perhaps, State governments, under pressure from voters, took the initiative in environmental protection in contravention of the Commonwealth's wishes. The point here is that overlapping responsibilities provide the opportunity for a wider range of interests to influence the policy debate, especially when there is a lack of agreement between the different governments.

The impact of the reduction in overlap is clear when we look at two proposals to build pulp mills in northern Tasmania almost twenty years apart (Curran and Hollander 2008). In both cases, the State government resisted community pressure and expert advice, using its authority to push plans through parliament. In 1989, however, the Commonwealth, using the foreign investment approvals process, was able to undertake a more wide ranging assessment of the project (Economou 1992). By contrast, under the EPBC Act, the Commonwealth oversight was limited to MNES, in this case the impact on the marine environment and endangered species (Australia no date). In other words, under the new regime the Commonwealth capacity to intervene was much more constrained.

These examples show that overlapping authority provides an additional arena to assess the 
merits of a proposed development. In situations where one level of government has been prepared to sanction an expedited environmental assessment process, as occurred in relation to Tasmania’s Wesley Vale pulp mill proposal, overlap can serve as Landau’s “fail-safe”. The drive to eliminate overlap has reduced the self correcting capacity of the system with one level of government is unable to "correct" the errors of another. The fail-safe mechanism is important because of the nature of policy domain which is characterised by high levels of uncertainty and unpredictability. Moreover, ESD with its emphasis on future generations and the precautionary principle implies a degree of caution because what is lost cannot necessarily be recovered.

Overlap is also important in a two party parliamentary system, where there are limited checks and balances on government between elections and ministers are allowed a great deal of discretion (see Kelemen 2004). As we have seen, the EPBC Act gave Commonwealth Environment Ministers wide discretion in the way projects were assessed. State regimes were even more liberal providing Ministers with the power to over ride the decisions of delegated authorities. The implications of this were clear in the Tamar Valley case where the Tasmanian Premier, after failing to influence the formal assessment process, abandoned it altogether and shepherded specific purpose legislation through the Parliament (Herr 2007; Gale 2008). In this case the government, determined to approve the Tamar Valley pulp mill, despite significant community opposition (see for example Clarke 2007; Gordon 2008; Wilderness Society 2007). The Tamar Valley case can provide us with a good example of Elazar's $(1985,33)$ observation that “popular government is not only not enhanced by simple majoritarianism but is often defeated by it”.

The clear delineation of roles and responsibilities removes one possible brake on government power allowing it to pursue measures at odds with majority aspirations with impunity, in the short term at least. It effectively does away with the republican rationale of federalism itself the containment of government (Beer 1993). 


\section{CONCLUSION}

Over the last two decades successive Commonwealth and State governments have sought to eliminate the overlap and duplication which characterised the Australian federation as a way of "fixing federalism" (Rudd 2007). As this discussion shows, in the area of environmental assessment and approval, they have largely achieved their goal eliminating much of the overlap which had characterised the former regime. From the early 1990s onwards, a more streamlined system gradually replaced the hotchpotch of overlapping powers and unpredictable outcomes. Whilst there remained considerable difference between the various State and Territory regimes, they also had much in common including a shared conceptual framework of ESD. More importantly, the Commonwealth's role became much clearly delineated. It assumed responsibility for the MNES - those matters it deemed to be of national or international interest. There were also efforts to eliminate duplication of process and the Commonwealth accepted paperwork which had been prepared to meet State government requirements. Whilst this simplification may have generated savings to both business and government, it was problematic for two reasons. First, the complexity of the policy domain defies efforts to divide it neatly between jurisdictions especially given our limited understanding of the ways in which natural systems work. Second, it has reduced the opportunities to debate the merits of particular proposals. Whereas, in the past, interest groups could appeal to another level of government, the new regime closed these avenues off. The new regime effectively increased the capacity of government either at State or Commonwealth level, to act unilaterally.

Whilst this analysis is based on a single policy area in a single country, its findings suggest broader implications. The new Australian environmental approval and assessment regime was driven by political and administrative imperatives. It aimed to minimise duplication and overlap to increase efficiency and predictability. This is a common enough aspiration amongst jurisdictional federations such as Australia, Canada and the United States. Federations, with their multiple levels of government, and overlapping jurisdictions, are an 
anathema to the contemporary approach to public management, which stresses simplicity and streamlining. The concern for administrative efficiency fails to appreciate the potential of a less tidy policy framework. The promise of federalism was, and is, its capacity to provide more than one opportunity for political interaction and its capacity to contain unilateral action by government. Indeed, Kincaid (1995) argues one of federalism's great strengths is that it,

... offers citizens multiple points of access to public power [and] opportunities to appeal to other governments on certain matters when one is unresponsive. Multiple governments can also check and balance each other in various ways, including competition and cooperation, thereby curbing centrifugal tendencies toward anarchy and centripetal tendencies toward monopoly.

This can only occur, however, in situations where layer cake gives way to marble cake - in situations of concurrency. We need to ask if overlap and duplication is really a sign of a dysfunctional political system or if concurrency acts as a fail-safe in situations where the individual parts are far from perfect. Landau $(1969,356)$ contends ,

if there is no duplication, if there is no overlap, if there is no ambiguity, an organization will neither be able suppress error, nor generate alternative routes of action ... it will be most unreliable and least flexible.

We could well say the same of a federation.

\footnotetext{
${ }^{1}$ Of course duplication and overlap is not Australian federalism's only problems. A.J. Brown (2006), for example, points to its failure to formally recognise and appreciate local and regional spheres of government.

${ }^{2}$ Overlap and duplication are characteristic of 'jurisdictional' federations. The co-operative model of federalism, typified by Germany, is characterised by a functional division of roles and responsibilities and this has traditionally generated less anxiety about overlap and duplication although unification however has brought new strains (See for example Merkl 1959; Benz 1998; Adelberger 2001).

${ }^{3}$ See Burgess (2006) for a comprehensive review of this literature.

${ }^{4}$ Following Riker, Stepan (1999) distinguishes between federations which "come together" when formerly independent entities unify and those that are formed by unitary countries in an attempt to "hold together".

${ }^{5}$ Not unsurprisingly, the concept of 'the environment', did not figure in the constitution and responsibility for law making in relation to land, mining, local government, fisheries, forests, water resources and the like remained a State responsibility (Zines, 1985, 13).

${ }^{6}$ See Anderson and Parkin (2007) for discussion of the 1998 Goods and Services Tax and its capacity to enhance State autonomy.

7 The 1982 Koowata case confirmed the Commonwealth's power to override racially discriminatory law in Queensland and the 1984 Tasmanian Dam case recognised the Commonwealth's intervention in Tasmania to prevent the construction of a dam in a World Heritage listed area. (Edmonds 2000).
} 
${ }^{8}$ Selway and Williams ( 2005) argue that in the process of centralisation, the High Court has merely confirmed the powers of the central government whilst Allan and Arony (2008) contend it has in fact delivered an outcome at odds with the intentions of Australia's founders.

${ }^{9}$ See Saunders 2002 for background on the marble cake analogy and its application in Australian. Elazar (1984, xii) argues that over time Grodzins had become less enthusiastic about the analogy recognising that the layers remained distinct in some instances.

${ }^{10}$ See for example, ACER 1981, EPAC 1990,

${ }^{11}$ New Federalism has generated a considerable literature. See for example, Galligan and Walsh 1990; Wiltshire 1992; Galligan, 1995; Parkin, 1996; Painter 1998a,b; Saunders, 2002.

${ }^{12}$ See Hollander and Patapan $(2007,283-5)$ for a brief overview of the major political parties' attitudes to federalism.

${ }^{13}$ See Radbone (1982) for a discussion of the Interstate Commission. While the Australian Senate has rarely acted as a "States' House" as was intended, some argue that it nevertheless performs an important democratic function. See Stone (2002, 268), for a summary of the literature. See Russell $(2001,445)$ for a counter view.

${ }^{14}$ See Fletcher and Walsh 1992, esp 596-98; Willtshire 1992, 165

${ }^{15}$ See Stewart 1999; Davis 1998, 163; Galligan and Wright 2002, 154. Under the Howard government (1996-2007), COAG languished (Hollander and Patapan 2007, 287) but in 2007 incoming Prime Minister Rudd signalled a more significant role for the institution (Anderson 2008). On a broader level, Lynch and Williams 2008 argue that, without constitutional recognition, collaboration in Australia will remain vulnerable to the vagaries of politics.

${ }^{16}$ See Zines 1985 for an contemporary view of the constitutional position.

${ }^{17}$ Fraser Island located off the Queensland coast, is the world's largest sand island.

${ }^{18}$ The Franklin River flows through the Tasmania's south west.

${ }^{19}$ ESD was based on the notion of sustainability which gained international prominence following the publication of the World Commission on Environment and Development's 1987 Brundtland Report (Dryzek 2005, 145-6). Brundtland defined sustainable development as development that 'meets the needs of the present without compromising the ability of future generations to meet their own needs' (WCED 1987, 263). Sustainable development thus required that economic development be tempered by the capacity of ecological (and social) processes to renew themselves.

${ }^{20}$ See Ross and Dovers (2008) for discussion of environmental policy integration in Australia

${ }^{21}$ There is an emphasis on the "sustainable management" in Tasmania's forest practices code, however (Hollander 2006a).

${ }^{22}$ Local government, in Australia, is a legislative creation of State governments. A referendum which would have seen local government recognized in the Constitution was defeated in 1988.

${ }^{23}$ See for example Queensland's Integrated Planning Ac 1997; Tasmania's Land Use Planning and Approvals Act 199; and Western Australia's Planning \& Development Act 2005.

${ }^{24}$ The Wet Tropics are located in far North Queensland. The area received World Heritage status in 1989. 


\section{REFERENCES}

ACER (Advisory Council for Inter-government Relations) 1981. Towards adaptive federalism. Information Paper no. 9. Canberra: AGPS.

Adelberger, K. 2001. Federalism and its discontents: Fiscal and legislative power-sharing in Germany, 1948- 1999. Regional \& Federal Studies 11:2,43-68.

Agranoff, Robert and McGuire, Michael 2004. Another look at bargaining and negotiating in intergovernmental management. Journal of Public Administration Research and Theory 14(1): 495-512.

Allan, James and Aroney, Nicholas. 2008. An uncommon court: How the High Court of Australia has undermined Australian federalism. Sydney Law Review 30: 245-294.

Armit, Amelita and Bourgault, Jacques. 1995. Hard choices or no choices: Assessing program review. Regina: Institute of Public Administration of Canada.

Armingeon, Klaus. 2000. Swiss federalism in comparative perspective In Federalism and Political Performance ed. Ute Wachendorfer and Ute Wachendorfer-Schmidt. London: Routledge.

Auditor General. 2003. Annual reporting on ecologically sustainable development. Audit Report No. 41 2002-03. Australian National Audit Office. Canberra: AusInfo.

Australia. 1992a. Intergovernmental agreement on the environment. Canberra: Department of Environment, Water, Heritage and the Arts.

http://www.environment.gov.au/esd/national/igae/index.html. (accessed 24 July 2008).

Australia. 1992b. National Strategy for Ecologically Sustainable Development. Canberra: Department of Environment, Water, Heritage and the Arts, http://www.environment.gov.au/esd/national/nsesd/strategy/index.html (accessed 24 July 2008).

Australia. 2007. Annual Report 2006-07. Canberra: Department of the Environment and Water Resources.

Australia. 2008. Bilateral agreements and declarations. Canberra: Department on Environment and Heritage.

http://www.environment.gov.au/epbc/assessments/bilateral/index.html (accessed 22 July 2008).

Australia. 2008. Operation of Environmental Protection and Conservation Biodiversity Act 1999. Canberra:. Department of Environment and Heritage. http://www.environment.gov.au/epbc/publications/reports.html (accessed 5 August 2008). 
Australia. no date. Summary of conditions for the Gunns Limited proposed pulp mill. Fact Sheet. Canberra: Department of Environment and Water http://www.environment.gov.au/epbc/notices/assessments/2007/3385/pubs/summaryapproval-conditions.pdf (accessed 6 August 2008).

Baumgartner, Frank R. and Jones, Bryan D. 1991. Agenda dynamics and policy subsystems The Journal of Politics. 53 (4): 1044-1074.

Beer, S. H. 1993. To Make a Nation: The Rediscovery of American Federalism. Cambridge: Harvard University Press.

Benz, A. 1999. From unitary to asymmetric federalism in Germany: Taking stock after 50 years. Publius 29(4): 55-80

Birch A.H. 1966 Approaches to the study of federalism. Political Studies XIV(9): 15-33.

Bligh, Anna. 2008. Speech Anna Bligh MP Premier of Queensland at Inaugural ANZSOG Public Lecture. 4 July.

http://www.thepremier.qld.gov.au/library/office/ANZOG_040708.doc. (accessed 19 August 2008).

Boer, Ben. 1992. World heritage disputes in Australia. Journal of Environmental Law and Litigation 7: 247-79

Bonyhady, Tim. 1993. Places Worth Keeping: Conservationists, Politics and the Law. St Leonards NSW: Allen and Unwin.

Bowen, James and Bowen, Margarita. 2002. The Great Barrier Reef: History, Science and Heritage. Cambridge: Cambridge University Press.

Brown, A.J. 2006. Federalism, regionalism and the reshaping of Australian governance. In Federalism and Regionalism in Australia: New Approaches, New Institutions ed. A.J. Brown and Jennifer Bellamy. Canberra: ANU ePress.

Brown, Gordon, R. 1992. Canadian federal-provincial overlap and presumed government inefficiency. Publius. 24(1):21-37.

Brumby, John. 2008. Nation building. A paper from IPAA leadership speaks. 11 September. http://www.vic.ipaa.org.au/library/news/1192154899_document_11_september_2007 _-_nation_building_-_the_hon._john_brumby_mp.pdf. (accessed 19 August 2008).

Burgess, Michael. 2006. Comparative Federalism, London: Routledge.

Carroll, P. \& Painter, M. 1995. The federal politics of microeconomic reform: An overview and introduction. In Microeconomic Reform and Federalism Federalism. ed.. P. Carroll and M. Painter. Canberra: Federalism Research Centre, Australian National University.

CBD (Secretariat for the Convention of Biological Diversity). 2000. Sustaining Life on Earth. http://www.cbd.int/doc/publications/cbd-sustain-en.pdf. (accessed August 2008).

Chamberlain, Paul. 1992. A new era in federal-state relations Sydney Morning Herald, 12 
March: 16.

Chapman, Ralph J. K. 1990. Australian public policy, federalism, and intergovernmental relations: The federal factor. Publius, 20(4): 69-84.

Christoff, P. 1994. Environmental Politics. In Developments in Australian Politics. ed. J. Brett, J. Gillespie and M. Goot. Melbourne: Macmillan.

Christoff, P. 2002, In reverse: How far has Australia advanced in its environmental efforts since the first WSSD in 1992? Habitat Australia 30(5): 10 - 13.

Clark, Nick 2007. Poll pulps popularity claim. Mercury. 8 May.

Clayton Utz. 2005. Greenhouse gas: Legal challenge to EPBC decision. News 5 August. http://www.claytonutz.com/news/controller.asp?nid=761. (accessed 12 August 2008).

Cleary, Paul 1990. Uniform policy to be developed. Sydney Morning Herald, 31 October 1990: 6.

COAG (Council of Australian Governments). 1992. Council of Australian Governments' Communiqué Environment - ESD and Greenhouse 7 November. http://www.coag.gov.au/meetings/071292/i ndex.htm\#environment. (accessed 24 July 2008).

COAG (Council of Australian Governments) 1997. Heads of agreement on Commonwealth and State roles and responsibilities for the environment. Department of Environment, Heritage, Water and the Arts.

http://www.environment.gov.au/epbc/publications/coag-agreement/preamble.html (accessed 5 August 2008).

Curran, G. 1998. 'Environmental politics and policy making: Economic challenges to political decision making' In The Politics of Australian Society Political Issues for the New Century ed. P. Boreham, G. Stokes. and R. Hall. Frenchs Forest NSW: Longman.

Curran, Giorel and Hollander, Robyn. 2008. A tale of two pulp mills: Realising ecologically sustainable development in Australia. Australian Journal of Public Administration (forthcoming).

Cwlth (Commonwealth of Australia). 1998. Parliamentary Debates - Senate Hansard. 2 July: 4795-98.

Davis, Bruce, W. 1985. Federalism and environmental politics: An Australian overview. In Federalism and the Environment. ed. R.L. Mathews. Canberra: Centre for Research on Federal Financial Relations, AUSTRALIAN NATIONAL UNIVERSITY.

Davis, G. 1998. Carving out policy space for State government in a federation: The role of coordination. Publius 28(4): 147-165.

Davis, S.R. 1956. The federal principle reconsidered part II. Australian Journal of Politics and History 1(2): 223-244. 
Development Act 1993 (Sth Aust.)

Dion, Stéphane. 1996. Federalism: A system in evolution. Notes for an address to the APEX

Ottawa, Ontario, April 25. http://www.pco-

bcp.gc.ca/aia/index.asp?lang=eng\&Page=archive\&Sub=Speeches\&Doc=19960425_e .htm. (accessed 26 August 2008).

Dovers, Stephen 2001. The institutions of sustainability. Economics \& environment network. Australian National University. http://dspacedev.anu.edu.au/bitstream/1030.58/11754/2/een0101.pdf. (accessed 6 August 2008).

Dovers, Stephen. 2002. Sustainability: reviewing Australia's progress, 1992-2002. International Journal of Environmental Studies. 59(5):559-571.

Dryzek, J. 2005. The Politics of the Earth: Environmental Discourses. $2^{\text {nd }}$ ed. New York: Oxford University Press.

Economou, Nick. 2004. Politics and the environment policy debate. In The Politics of Australian Society: Political Issues for the New Century. 2nd ed. ed. Paul Boreham, Geoffrey Stokes, and Richard Hall. Frenchs Forrest, NSW: Pearson Longman: 357372

Edmonds, Thomas H. 2000. Queensland rainforest and wetlands conflict: Australian external affairs power - domestic control and international conservation'. Environmental Law 20: 387-410.

Elazar, Daniel, J. 1985. Federalism and consociational regimes. Publius. 15(2): 17-34.

Engel Kirsten H. 2006. Harnessing the benefits of dynamic federalism in environmental law. Emory Law Journal 56(1): 159-188.

England, Philippa 1999. Toolbox or tightrope? The stauts of environmental protection in Queensland's Integrated Planning Act. Environmental Planning and Law Journal. 16(2): 124-139.

Environmental Management and Pollution Control Act 1994 (Tas).

Environmental Planning and Assessment Act 1979 (NSW).

Environmental Protection Act 1986 (WA).

Environmental Protection and Biodiversity Conservation Act 1999 (C’wlth).

EPAC (Economic Planning Advisory Council). 1990. Towards a more co-operative federalism. Discussion paper 90/04. Canberra: AGPS.

Esty, Daniel, C. 1996. Revitalising environmental federalism. Michigan Law Review 95(3): 570-653.

Fenna, Alan. 2004. Australian Public Policy. Longman, Frenchs Forest NSW.

Fenna, Alan. 2008. Commonwealth fiscal power and Australian federalism, The University of New South Wales Law Journal 31(2):509-29. 
Field, M. 1992 Structures of federalism. American University Journal Review of International Law and Policy 8 445-453.

Fletcher, Christine, and Walsh, Cliff. 1992. Reform of intergovernmental relations in Australia: The politics of federalism and the non-politics of managerialism. Public Administration 70(4): 591-616.

Forest Practices Act 1985 (Tas).

Forestry Act 1920 (Tas).

FSRC (Federal-State Relations Committee). 1998. Report on Australian federalism: The role of the states. vol. 2. Parliament of Victoria http://www.parliament.vic.gov.au/fsrc/report2/body/chapter3.htm\#fn20. (accessed 26 October 2008).

Gale, Fred. 2008. Tasmania’s Tamar Valley pulp mill: A comparison of planning processes using a good environmetal governance framework. Australian Journal of Public Administration 67(3):261-82.

Galligan, Brian. 1993. Federalism and policy making. In Policy Making in Volatile Times. ed. Andrew Hede and Scott Prasser. Sydney, NSW: Hale \& Iremonger.

Galligan, B. 1995. A Federal Republic: Australia's Constitutional System of Government, Cambridge University Press: Cambridge.

Galligan, Brian 2008. Processes for reforming Australian federalism. The University of New South Wales Law Journal 31(2): 617-42.

Galligan, Brian and Walsh, Cliff. 1990. Australian federalism: Developments and prospects. Publius. 20 (4): 1-17.

Galligan, B. and Wright, J.S.F.. 2002. Australian federalism: A prospective assessment. Publius 32(2): 147-168.

Gleeson, Brendan. 2001. Devolution and State planning systems in Australia. International Planning Studies. 6(2) $133-152$.

Gordon, Josh. 2008. Almost two-thirds oppose pulp mill. Age 22 June.

Grodzins, Morton. 1984. The American system : a new view of government in the United States. ed. Daniel J. Elazar. New Brunswick,N.J.: Transaction Books,

Herr, R. 2007. Tasmania: January to June 2007 (Political Chronicles). The Australian Journal of Politics and History 53(4): 652-7.

Higgs, HJ. 1978. The Commonwealth experience with the environmental inquiry. In: Environmental Engineering Conference 1978: Environmental Enquiry. Barton: ACT: Institution of Engineers.

Hollander, R. 2004. Changing places?: Commonwealth and State government performance and regional forest agreements. Paper presented to the Australasian Political Studies Association Conference, University of Adelaide 29 September. 
Hollander, R. 2006a. Light-handed regulation: The case of the Tasmanian forest practices system. Australian Journal of Environmental Management. 13(1) 17-27.

Hollander, R. 2006b. National competition policy, regulatory reform and Australian federalism. Australian Journal of Public Administration 65(2): 33-47.

Hollander. R. and Patapan, H. 2007. Pragmatic federalism: Australian federalism from Hawke to Howard. Australian Journal of Public Administration 66(3): 280-297.

Howard, J. 2005a. Address to the Menzies Research Centre, Melbourne. Reflections on Australian federalism. 11 May. PM's Media Centre: Speeches by Hon John Howard. Canberra: Department of Prime Minister and Cabinet. http://www.pm.gov.au/news/speeches/speech1320.html. (accessed 2 February 2006). Howard, J. 2005b. Address to the Sydney Institute. Workplace relations reform: The next logical step. Four Seasons Hotel, Sydney 11 July. PM’s Media Centre: Speeches by Hon John Howard. Canberra: Department of Prime Minister and Cabinet. http://www.pm.gov.au/news/speeches/speech1455.html. (accessed 20 February 2006).

Howard, J. 2005c. Transcript of the Prime Minister the Hon John Howard MP address to the Queensland Liberal Party post budget luncheon. Hilton Hotel, Brisbane, 18 May. PM's Media Centre: Speeches by Hon John Howard. Canberra: Department of Prime Minister and Cabinet. http://www.pm.gov.au/news/speeches/speech1392.html. (accessed 14 October 2005).

Hutton, Drew and Connors, Libby 1999. A History of the Australian Environment Movement. Cambridge: Cambridge University Press.

Integrated Planning Act 1998 (Qld).

Keating, M. and Wanna, J. 2000. Remaking Federalism? In Institutions on the Edge? Capacity for Governance. ed. M. Keating, J. Wanna and P. Weller. St Leonards, NSW: Allen \& Unwin.

Kelemen, R. Daniel. 2004. The Rules of Federalism: Institutions and Regulatory Politics in the EU and Beyond. Cambridge: Harvard University Press

Kellow, Aynsley 1989. The dispute over the Franklin River and South West Wilderness Area in Tasmania, Australia. Natural Resources Journal 29:129-146.

Kellow, Aynsley. 1995. Federalism and environmental policy reform: Microeconomics and macropolitics. In Microeconomic Reform and Federalism. ed. P. Carroll and M. Painter. Canberra: Federalism Research Centre, Australian National University. Kellow, A. \& Niemeyer, S. 1999. The development of environmental administration in Queensland and Western Australia: Why are they different? Australian Journal of Political Science 34(2): 205-22. 
Kennedy, M., Beynon, N. Graham, A. and Pittock, J. 2001. Development and implementation of conservation law in Australia. Review of European Community and International Environment Law 10(3): 290-308.

Land Use Planning and Approvals Act 1993 (Tas.)

Landau, Martin. 1969. Redundancy, rationality, and the problem of duplication and overlap. Public Administration Review. 29 (4): 346-358.

Lee, Dwight R. 1994. Reverse revenue sharing: A return to fiscal federalism. Cato Journal 14(1): 75-85.

Lines, William J. 2008. Patriots: Defending Australia's Natural Heritage. St Lucia: University of Queensland Press.

Macintosh, Andrew 2004. Why the Environment Protection and Biodiversity Conservation Act's referral, assessment and approval process is failing to achieve its environmental objectives. Environmental Planning and Law Journal 21: 288-311.

Macintosh, Andrew and Wilkinson, Debra. 2005. Environment Protection and Biodiversity Conservation Act A five year assessment. Discussion Paper Number 81. Sydney: Australia Institute.

McGrath, Chris. 2001. The flying fox case. Environment and Planning Law Journal 18(6): 540-65.

McGrath, Chris. 2004. Key concepts of the Environment Protection and Biodiversity Conservation Act 1999 (C’th). Environmental Planning and Law Journal 22: 20-39.

McGrath, Chris 2008. Flying foxes, dams and whales: Using federal environmental laws in the public interest. Environmental Planning and Law Journal 25: 324-59.

Mercer, David and Marden, Peter 2006. Ecologically sustainable development in a "quarry" economy: One step forward, two steps back. Geographical Research 44(2): 183-203.

Merkl, Peter H. 1959. Executive-legislative federalism in West Germany. The American Political Science Review. 53(3): 732-74 .

Miller, Peter and Rees, William E. 1993. Introduction. In Ecological integrity and the Management of Ecosystems. eds Stephen Woodley, James Kay, George Francis Delray Beach, Fla.: St. Lucie Press.

Mulligan, Martin and Hill, Stuart. 2001. Ecological Pioneers: A Social History of Australian Ecological Thought. Cambridge: Cambridge University Press.

NSW, 2007. What is considered a major project? Major Projects Assessment System: Fact Sheet 2. Department of Planning. www.planning.nsw.gov.au/assessingdev/pdf/Sep07\%20FS2_WhatIsMajProj\%20NE W.pdf (accessed 30 July 2008). 
O’Toole, Laurence J. 1990. Theoretical developments in public administration: Implications for the study of federalism. Governance: An International Journal of Policy and Administration 3(4): 394-415.

Painter, Martin 1998a. After managerialism - rediscovers and redirections: The case of intergovernmental relations. Australian Journal of Public Administration 57(4): 4753.

Painter, Martin. 1998b. Collaborative Federalism. Cambridge: Cambridge UP.

Parkin, Andrew, 1996. The significance of federalism: A South Australian perspective. In South Australia, Federalism and Public Policy. ed. A. Parkin Canberra: Federalism Research Centre, AUSTRALIAN NATIONAL UNIVERSITY.

Parkin, Andrew 2003. The States, federalism and political science: A fifty year appraisal Australian Journal of Public Administration. 62(2): 102-112.

Parkin, Andrew and Geoff Anderson. 2007. The Howard government, regulatory federalism and the transformation of Commonwealth-State relations. Australian Journal of Political Science 42(2): 295-314.

Peel, J. and Godden, L. 2005. Australian environmental management: A “dams” story. UNSW Law Journal 28(3): 668-95.

Petersen, Paul E. 1995. The price of federalism. Washington: Brooking Institute Press. Pincus, Jonathan. 2008. Six myths of federal-state financial relations. CEDA. http://ceda.com.au/public/research/federal/six_myths_federal_state.html. (accessed 4 November 2008).

Planning and Environment Act 1987 (Vic.)

Pope, Jenny, Annandale, David, and Morrison-Saunders, Angus. 2004. Conceptualising sustainability assessment. Environmental Impact Assessment Review. 24 595-616

Productivity Commission. 1999. Implementation of ecologically sustainable development by Commonwealth departments and agencies. Report No. 5. Canberra: AusInfo.

Rabe, Barry 2007a Beyond Kyoto: Climate change policy in multilevel governance systems. Governance 20(3): 423-444.

Rabe, Barry 2007b Environmental policy and the Bush era: The collision between the administrative presidency and state experimentation. Publius. 37(3):413-431.

Rabe, Barry 2008. States on steroids: The intergovernmental odyssey of American climate policy. Review of Policy Research. 25(2): 105-128.

Radbone, Ian. 1982. The Inter-state Commission. Australian Journal of Public Administration XLI(4): 323-38.

Resource Planning and Development Act 1997 (Tas.).

Richardson, Jeremy . 2000. Government, Interest Groups and Policy Change. Political Studies: 48: 1006-1025 
Ross, Andrew, and Dovers, Stephen. 2008. Making the harder yards: Environmental policy integration in Australia. Australian Journal of Public Administration 67(3): 245-60.

Rudd, K. 2007. Speech to Australian business economists. New leadership for the Australian federation: Fixing federalism and fixing the Australian health care system. 4 October. http://www.alp.org.au/media/1007/speloo040.php. (accessed 17 July 2008).

Rudd, K. 2008a. Address to heads of agencies and members of Senior Executive Service. Great Hall, Parliament House, Canberra, 30 April. http://www.pm.gov.au/media/Speech/2008/speech_0226.cfm. (accessed 21 July 2008).

Rudd, K. 2008b. Interview with Chris Uhlmann, ABC TV News, 20 April. http://www.pm.gov.au/media/Interview/2008/interview_0211.cfm. (accessed 21 July 2008).

Rudd, K. 2008c. Interview with Paul Borgiorno. Network Ten News. 20 April. http://www.pm.gov.au/media/Interview/2008/interview_0209.cfm. (accessed 21 July 2008).

Rudd, K. 2008d. Joint doorstop interview with Treasurer Wayne Swan. Suncorp Stadium, Brisbane. 30 May. http://www.pm.gov.au/media/Interview/2008/interview_0278.cfm. (accessed 21 July 2008).

Rudd, K. 2008e. Preparing Australia for the challenges of the future. Address to the Western Australian Chamber of Commerce and Industry breakfast, Perth 07 May. http://www.pm.gov.au/media/Speech/2008/speech_0237.cfm. (accessed 21 July 2008).

Russell, Meg 2001. What are second chambers for? Parliamentary Affairs 54: 442-458

Salvail, Michelle, 1992. Federal-Provincial program overlap. Economics Division, Government of Canada. http://dsp-psd.tpsgc.gc.ca/Collection-R/LoPBdP/BP/bp321e.htm\#NATURE,\%20CAUSES\%20AND\%20CONSEQUENCES\%20OF\%20OVER LAP(txt). (Accessed 17 July 2008).

Saunders, Cheryl. 2002. Collaborative federalism. Australian Journal of Public Administration 61(2):69-77.

Sawer, G. 1969. Modern Federalism. London: Pitman Publishing.

SDPWO (State Development and Public Works Organisation Act) (Queensland)

Selway, Bradley and Williams, John M. 2005. The High Court and Australian federalism. Publius 35(3) 467-88.

Sewell, W.R. Derrick, Dearden, Philip and Dumbrell, John. 1989. Wilderness decisionmaking and the role of environmental interest groups: A comparison of the Franklin Dam, Tasmania and South Moresby, British Columbia cases. Natural Resources Journal 29:147-69.

State Policies and Projects Act 1993 (Tas.) 
Stepan, Alfred 1999. Federalism and democracy: Beyond the U.S. model. Journal of Democracy 10.4: 19-34.

http://muse.jhu.edu/journals/journal_of_democracy/v010/10.4stepan.html (accessed 6 October 2008).

Stewart, A. and Williams, G. 2007. Work choices: What the High Court Said. The Federation Press, Sydney.

Stewart, J. 1999. The Howard government and federalism: The end of an era?' In The Howard Government Australian Commonwealth Administration 1996-1998. ed. G. Singleton. Sydney: UNSW Press.

Stone, Bruce. 2002. Bicameralism and democracy: The transformation of Australian State upper houses. Australian Journal of Political Science 37(2): 267-281

Tasmania. 2003. Guide to the Resource Management and Planning System. Resource Planning and Development Commission.

Tasmania. 2008a. Environmental impact assessment: A guide. Department of Environment, Parks, Heritage and the Arts, March 2008 http://www.environment.tas.gov.au/_downloads/EIA\%20-\%20A\%20Guide.pdf (accessed 31 July 2008).

Tasmania. 2008b. Environment impact assessment role of EMPC Board and Council. Department of Environment, Parks, Heritage and the Arts, January http://www.environment.tas.gov.au/_downloads/Board\%20and\%20Council\%20Asses sment\%20Roles.pdf. (accessed 31 July 2008).

Thom, Bruce. 2004. Geography, planning and the law: A coastal perspective. Australian Geographer 35(1): 3-16.

Thomas, Nick and Daniel, Rachel. 2007. Court hammers Anvil Hill challenge. Clayton Utz Energy and Resources Insights. 13 December. http://www.claytonutz.com.au/areas_of_law/controller.asp?aolstring=\&na=1646. (accessed 12 August 2008).

Thorlakson, Lori 2003. Comparing federal institutions: power and representation in six federations. West European Politics, 26 (2): 1-22

Twomey, Anne. 2007. The reform of Australia's federal system. Legal Studies Research Paper 07/80. Sydney Law School University of Sydney. http://ssrn.com/abstract=1033180. (accessed 17 July 2008).

Twomey, Anne and Withers, Glenn. 2007. Federalist papers one Australia’s federal future. A Report prepared for the Council for the Australian Federation. April. http://www.dpc.vic.gov.au/CA256D800027B102/Lookup/FederalistPaperAustralia'sF ederalFuture/\$file/Federalist\%20Paper\%20Australia's\%20Federal\%20Future.pdf (accessed 17 July 2008). 
Victoria. 2006. Ministerial guidelines for assessment of environmental effects under the

Environmental Effects Act 1978. $7^{\text {th }}$ ed. Department of Sustainability and Environment.

http://www.dse.vic.gov.au/CA256F310024B628/0/6243C40E42C9449DCA25719C0

01D2DF4/\$File/DSE097_EES_FA.pdf.(assessed 2 August 2008).

Walker, K.J. 1999. Statist developmentalism in Australia. In Australian Environmental

Policy 2 ed. K. Walker \& K. Crowley. Kensington: UNSW Press. .

Walker, K,J. and Crowley, K. 1999. Introduction, In Australian Environmental Policy 2 ed.

K. Walker and K. Crowley. Kensington: UNSW Press.

Walsh, Cliff 2008. The economics of federalism and federal reform. The University of New

South Wales Law Journal 31(2): 553-82

Wanna, John and Weller, Patrick. 2003: Traditions of Australian governance. Public

Administration 81(1): 63-94.

Warner, Kenneth O. 1931. Australian federalism at the crossroads. Pacific Affairs 4 (2): 120141.

WCED (World Commission on Environment and Development). 1987. Our Common Future. Oxford: Oxford University Press.

Wheare, K. C. 1963. Federal Government. $4^{\text {th }}$ ed. Oxford: Oxford University Press.

Whitlam, G. 1983. The cost of federalism. In Australian Federalism Future Tense. ed. Allen Patience and Jeffrey Scott. Melbourne: Oxford University Press.

Wilderness Society Tasmania.. 2007. Opinion poll shows clear majority of Bass voters opposed to pulp mill. Media Release 31 August. http://www.wilderness.org.au/articles/basspoll. (accessed 22 August 2008).

Wiltshire, Kenneth. 1992. Australia's new federalism: Recipes for marble cakes. Publius. 22(3): 165-180.

Zines, Leslie. 1985. The environment and the constitution. In Federalism and the Environment. ed. R.L. Mathews. Canberra: Centre for Research on Federal Financial Relations. 